\title{
Peningkatan Produktivitas Usaha Keripik Singkong Melalui Pelatihan dan Pendampingan Teknologi Tepat Guna di Desa Sumber Anyar Kabupaten Bondowoso
}

\author{
Nian Riawati ${ }^{1}$ dan Nurcahyaning D.K ${ }^{2}$ \\ ${ }^{1}$ Program Studi Adminitrasi Negara, Universitas Jember \\ ${ }^{2}$ Program Studi DIII Perpajakan, Universitas Jember \\ E-mail : nian.fisip@unej.ac.id
}

DOI: http://dx.doi.org/10.21107/pgd.v5i1.5156

\begin{abstract}
Abstrak
Artikel Diterima : 5 Januari 2019/ Revisi : 17 Februari 2019/Terbit : 15 April 2019

Desa Sumber Anyar Kecamatan Maesan Kabupaten Bondowoso adalah Desa dengan potensi wilayah perkebunan yang luas dengan produksi singkong yang melimpah. Potensi tersebut belum dimanfaatkan dengan baik oleh masyarakatnya. Banyaknya masyarakat Desa Sumber Anyar dengan usia produktif yang menganggur dan sedikitnya kelompok usaha bersama merupakan penyumbang angka kemiskinan di Desa Sumber Anyar. Upaya untuk menurunkan angka kemiskinan perlu dilakukan. Salah satunya adalah dengan mengembangkan potensi daerah, yaitu mengolah singkong menjadi keripik yang mempunyai nilai ekonomis. Untuk itu perlu dilakukan program pelatihan dan pendampingan kepada Kelompok usaha keripik singkong di Desa Sumber Anyar. Kegiatan ini dibagi menjadi dua kegiatan. Kegiatan pertama melakukan Focus Group Discussion (FGD) memberikan pengetahuan mengenai standart kelengkapan produksi seperti No PIRT, keterampilan inovasi rasa dan pengemasan yang baik. Hasil dari FGD diformulasikan menjadi agenda kegiatan. Setelah mendapatkan hasil dari kegiatan FGD kemudian di aktualisasikan dengan melakukan praktek pelatihan dan pendampingan pembuatan keripik singkong. Tim pelaksana berusaha menciptakan suatu ide kreatif dan ide inovatif untuk memberikan nilai tambah terhadap komoditas keripik singkong di Desa Sumber Anyar. Salah satunya dengan mengubah cara produksi dengan menggunakan peralatan teknologi tepat guna sehingga kapasitas produksi dapat meningkat.
\end{abstract}

Kata Kunci : keripik singkong, teknologi tepat guna, produktivitas

\section{PENDAHULUAN}

Desa Sumber Anyar Kecamatan Maesan merupakan wilayah di Kabupaten Bondowoso yang memiliki luas areal keseluruhan sebesar \pm 388,57 ha, terdiri dari Sawah 95,87 ha, Bangunan/pekarangan 50,24 dan tegal/ladang 240,26 ha (sumber: Profile Desa Sumber Anyar Kecamatan Maesan). Sebagian Besar luas wilayah di Desa Sumber Anyar adalah sawah dan ladang. Sawah dan ladang merupakan sektor perekonomian utama di Desa tersebut yang dapat dimanfaatkan untuk kesejahteraan masyarakat Desa Sumber Anyar.

Pemanfaatan lahan oleh masyarakat Desa Sumber Anyar diantaranya Tanaman padi, jagung, ubi jalar, ubi kayu dan kacang tanah. Beberapa home industry di Desa Sumber Anyar adalah sentra usaha keripik singkong. Masyarakat Desa Sumber Anyar memanfaatkan potensi desa singkong yang melimpah tersebut dengan membuat usaha keripik singkong yang dapat memberikan nilai tambah secara ekonomis.
Singkong merupakan salah satu produk pertanian yang bisa dijadikan unit bisnis, karena manfaat yang diperoleh dari komoditas singkong cukup banyak salah satunya adalah dengan mengolah singkong menjadi keripik karena pangsa pasar keripik masih sangat luas.

Beberapa usaha keripik singkong yang menjadi khalayak sasaran dalam pengabdian ini adalah Usaha Keripik Singkong "Pak Mul'. Beberapa kelebihan unit usaha keripik singkong tersebut mempunyai produktivitas keripik yang tinggi dengan kapasitas produksi $15 \mathrm{Kg}$ keripik setiap harinya sehingga setiap bulan rata -rata memproduksi $450 \mathrm{Kg}$ keripik setiap bulannya.

Namun beberapa kelemahan yang diperoleh berdasarkan hasil observasi, industri rumahan keripik singkong yaitu usaha keripik singkong "Pak Mul" masih menggunakan peralatan sederhana. Proses pengirisan keripik singkong masih menggunakan pengiris singkong manual. Hasil dari proses pengirisan tidak maksimal 
dengan hasil irisan yang tidak sempurna sehingga berpengaruh pada kualitas keripik singkong yang dihasilkan. Selain itu, industry rumahan keripik singkong ini menjual keripik menggunakan kemasan plastik besar dan belum mempunyai standart produksi seperti No P-IRT.

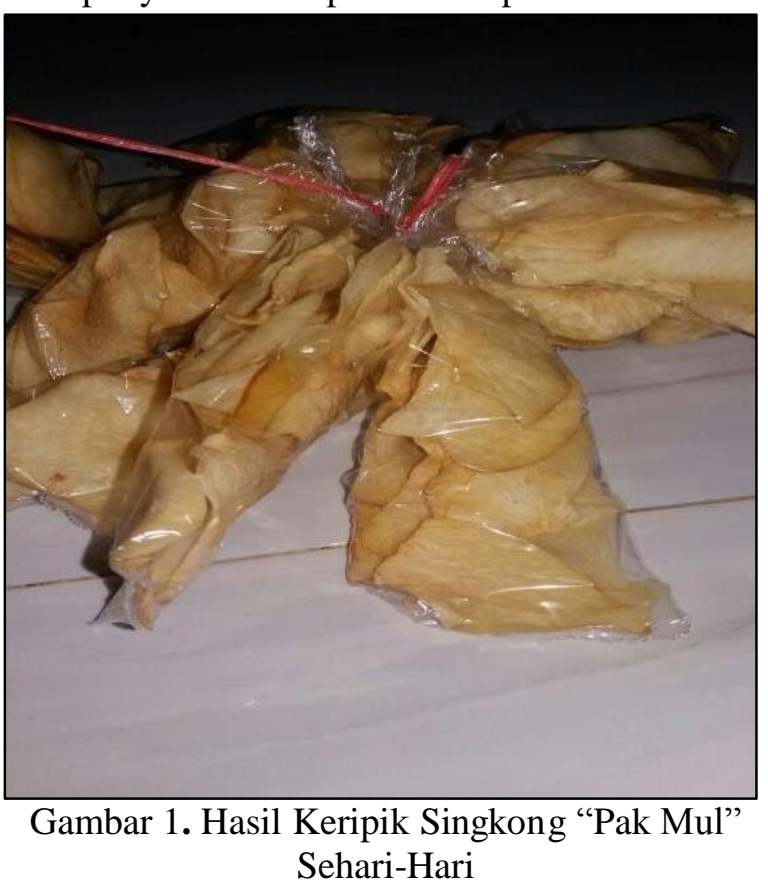

Selain itu potensi Sumber daya manusia di Desa Sumber Anyar Kecamatan Maesan cukup besar untuk memaksimalkan potensi sumber daya alam yang ada di desa tersebut. Jumlah Penduduk di Desa Sumber Anyar Kecamatan Maesan sebanyak 6.183 yang terdiri atas laki-laki sebanyak 2.872 orang dan perempuan 3.151 orang. Berdasarkan data tersebut jumlah penduduk perempuan lebih banyak daripada lakilaki. Ibu-ibu rumah tangga berpotensi untuk dapat membuka sentra usaha keripik singkong guna menunjang pendapatan suaminya untuk memenuhi kebutuhan rumah tangga.

Sedangkan jumlah angkatan kerja di Desa Sumber Anyar sebanyak 4.014 orang. Jumlah angkatan kerja terbanyak yaitu penduduk yang tidak tamat SD/sederajat yaitu sebayak 2.145 orang (BPS Kab Bondowoso, 2016). Penduduk di Desa Sumber Anyar banyak yang belum bekerja yaitu sebanyak 3.421 orang. Banyaknya penduduk yang belum bekerja disebabkan karena rendah tingkat ketrampilan yang mereka miliki karena disebabkan tingkat pendidikan yang rendah.

Jumlah pemilik usaha hanya sedikit yaitu 30 unit usaha seperti Home industry keripik singkong, krupuk patollah, anyaman bambu dan lain-lain. Jumlah tersebut sangat kurang untuk mendukung peningkatan kesejahteraan masyarakat. Masyarakat di Desa Sumber Anyar banyak yang menjadi buruh tani yaitu sebanyak 4.102 orang. Rendahnya keterampilan yang dimiliki masyarakat membuat masyarakat tersebut tidak dapat bekerja di tempat yang lebih baik. Berdasarkan potensi wilayah yang sebagian besar adalah sawah dan tegalan sebagian besar masyarakatnya menanam padi, tembakau, cabe dan singkong. Potensi Sumber daya manusia yang sebagian besar penduduknya adalah ibu-ibu rumah tangga menjadi salah satu modal pembentukan sentra keripik singkong di Desa Sumber Anyar Kecamatan Maesan.

Berdasarkan uraian tersebut diatas dapat dirumuskan beberapa permasalahan yang dihadapi kelompok usaha keripik singkong di Desa Sumber Anyar Kecamatan Maesan Kabupaten Bondwoso adalah sebagai berikut:

1. Terbatasnya keterampilan mitra dalam inovasi rasa dan proses pengemasan yang baik

2. Terbatasnya pengetahuan mengenai kelengkapan produksi seperti No PIRT

3. Belum menggunakan teknologi tepat guna untuk menghasilkan keripik singkong yang berkualitas dan menigkatkan produktivitas

4. Lemahnya kelompok usaha bersama sehingga belum tercipta sentra keripik singkong di Desa Sumber Anyar.

5. Potensi wilayah di bidang perkebunan yang belum dimanfaatkan secara optimal.

\section{METODE}

Untuk mengatasi persoalan yang dihadapi oleh kedua mitra pelaku usaha keripik singkong di Desa Sumber anyar, digunakan metode yang diuraikan dalam beberapa tahapan yang meliputi Focus Group Discussion (FGD) dan pelatihan dan pendampingan. Secara rinci, metode pelaksanaan yang digunakan adalah sebagai berikut :

\section{Focuss Group Discusion (FGD)}

Sebelum kegiatan pembuatan keripik singkong terlebih dahulu akan dilaksanakan Focuss Group Discusion (FGD). FGD ini dilakukan dengan tujuan menjaring keinginan kedua mitra meliputi kendala-kendala secara lebih spesifik dalam menjalankan usaha dan diskusi untuk mencari solusi yang ingin dipecahkan. Metode ini dilakukan dengan menggunakan metode ceramah dan diskusi.

Metode Ceramah akan dilakukan oleh tim pengusul untuk memberikan pengetahuan kepada kedua mitra mengenai inovasi rasa, pengetahuan mengenai kelengkapan produksi 
seperti No PIRT, penggunaan tekhnologi tepat guna yaitu mesin pengiris singkong otomatis dan memperluas pangsa pasar dengan menjalin kerjasama dengan toko oleh oleh serta memanfaatkan tekhnologi informasi seperti online market.

\section{Kegiatan pembuatan keripik singkong}

Setelah dilakukan FGD, Hasil dari kegiatan FGD di tuangkan dalam bentuk kegiatan pembuatan keripik singkong. Dalam pelatihan ini, Kedua mitra akan dikenalkan pada tekhnologi tepat guna mesin pengiris singkong otomatis skala industry dan cara penggunaan. Selain itu juga keterampilan mengenai proses pengemasan yang baik termasuk membuat label produksi yang dilengkapi No PIRT.

\section{HASIL DAN PEMBAHASAN}

Pengusaha Keripik Singkong rumah tangga di Desa Sumber Anyar Kecamatan Maesan pada awalnya banyak mengalami permasalahan dalam menjalankan usahnya. Beberapa permasalahan tersebut antara lain Kapasitas Produksi yang rendah, kualitas produksi yang rendah, harga jual yang rendah dan pemasaran produk yang masih terbatas. permasalahan-permasalahan tersebut membuat usaha keripik singkong tidak mampu menopang kehidupan ekonomi. Permasalahan tersebut muncul karena selama ini pengusaha keripik singkong rumah tangga memproduksi keripik singkong secara manual dan konvensional. Pengusaha keripik singkong Desa Sumber Anyar hanya menjual hasil keripiknya menggunakan pengemas plastik sederhana dan menjualnya ke warung-warung kecil yang ada di Desa Sumber Anyar. Pengusaha keripik Singkong Rumah tangga melakukan proses produksi dan pemasaran secara konvensional karena keterbatasan ilmu pengetahuan dan tekhnologi yang dimiliki kedua posdaya tersebut.

Kegiatan pengabdian ini dilaksanakan dalam rangka memberikan solusi kreatif dan inovatif dalam memecahkan permasalahan yang dihadapi kedua posdaya selama ini. Dalam kegiatan ini mitra akan diberikan tekhnologi tepat guna, pelatihan dan pendampingan bagaimana memproduksi keripik singkong yang berkualitas dan dikemas secara baik sehingga lebih tahan lama. Kegiatan ini dilakukan melalui dua Kegiatan. Kegiatan pertama melakukan pertemuan untuk melakukan Focus Group Discussion (FGD) untuk menggali permasalahan yang ada di Desa Sumber Anyar dan kemudian memformulasikan menjadi agenda kegiatan.
Pertemuan kedua setelah mendapatkan hasil dari kegiatan FGD tersebut kemudian di aktualisasikan dengan melakukan praktek pelatihan dan pendampingan pembuatan keripik singkong dengan satu mitra usaha keripik singkong terpilih yaitu usaha keripik singkong "Pak Mul". Dalam kegiatan pengabdian ini, tim pelaksana program berusaha menciptakan suatu ide kreatif dan ide inovatif untuk memberikan nilai tambah terhadap komoditas keripik singkong di Desa Sumber Anyar Kecamatan Maesan. Salah satunya dengan mengubah cara produksi dengan menggunakan peralatan modern sehingga kapasitas produksi dapat meningkat. Kemudian memasarkan keripik singkong dalam kemasan yang berkualitas baik serta label yang menarik sehingga dapat meningkatkan harga jual keripik singkong serta memperluas wilayah pemasarannya.

\section{Hasil FGD Kelompok Usaha Keripik Singkong}

Kelompok usaha keripik singkong di Desa Sumber Anyar ini melakukan beberapa tahapan selama proses produksi keripik singkong mereka. Tahapan tersebut antara lain:

- Tahapan persiapan bahan baku

a. Ketersediaan bahan baku

b. Bahan baku yang dibutuhkan

c. Perlakuan atas bahan baku

- Tahap pengolahan

a. Pemotongan/ pengirisan

b. Pengolahan mutu rasa/ bumbu

c. Tahap penggorengan

- Tahap pengemasan

a. Bahan baku kemasan

b. Merk

c. Proses pengemasan

- Tahap pemasaran

a. Model pemasaran, dan

b. Jangkauan pemasaran

Untuk perlakuan terhadap singkong yang sudah dipotong dan direndam kemudian langsung digoreng dengan sebelumnya bumbu dimasukan ke dalam penggorengan. Setelah digoreng, sebagian kelompok usaha keripik singkong ada yang memberi perlakuan dengan cara menambahkan pewarna makanan, dan ada juga yang tidak memberikan apapun. Hal ini bertujuan untuk menambah citra rasa keripik singkong yang mereka jual. Dari semua jenis keripik singkong yang diberikan perlakuan seperti di atas, keripik singkong dengan pewarna makanan jauh lebih cepat terjual dibandingkan keripik yang hanya diberi perlakuan air gula. 
Untuk tahap pengolahan, yakni pada saat pemotongan/ pengirisan singkong membutuhkan waktu yang lebih lama, karena pemotongan/ pengirisan singkong hanya dilakukan secara manual/ tradisional, yaitu dengan menggunakan pasrat. Pemotongan/ pengirisan dengan menggunakan pasrat ini tidak bisa dilakukan secara cepat, karena akan mengakibatkan jari terluka jika tidak berhati-hati. Kemudian pada tahap pengolahan mutu rasa/ bumbu, hampir sebagian besar kelompok usaha keripik singkong di Desa Sumber Anyar banyak yang memberikan penyedap makanan ke keripik singkong yang telah mereka goreng. Penyedap makanan ini diberikan dengan cara ditaburi di atas keripik yang sudah dimasukkan ke dalam dalam toples, lalu ditutup dan dikocok sampai penyedap/ bumbunya merata. Kendala yang ditemukan pada tahap pengolahan mutu rasa/ bumbu ini adalah bumbu yang tersedia di kelompok usaha keripik singkong ini hanya bumbu balado, sementara bumbu rasa lain seperti rasa berbeque dan lainlain susah untuk didapatkan. Hal ini dikarenakan beraneka rasa bumbu tersebut hanya terdapat di pusat kota Kabupaten Bondowoso, sehingga jarak tempuh yang mereka lalui untuk mendapatkan bumbu tersebut sangat jauh dan lama.

Proses yang dilakukan saat penggorengan adalah singkong dimasukkan ke dalam wajan yang minyaknya sudah panas lalu diaduk agar tidak sampai hangus dan masaknya merata. Untuk singkong yang sudah dibumbui dengan air gula, saat penggorengan keduanya harus dipisah agar tidak lengket satu sama lain. Kendala yang ditemui saat proses penggorengan ini adalah singkong yang direndam dengan air gula setelah digoreng rasanya agak keras saat digigit.

Untuk tahap pengemasan, bahan baku kemasan yang digunakan adalah bahan yang sederhana dan gampang didapatkan yaitu plastik kecil ukuran 250 gram. Bahan baku untuk proses pengemasan ini tersedia hampir di sebagian besar warung yang ada di sekitar Desa Sumber Anyar. Untuk merk dagang usaha keripik singkong ini, sebagian besar kelompok usaha keripik singkong di desa ini sudah memiliki merk, dan hanya sebagian kecil yang belum menggunakan merk. Bagi kelompok usaha keripik singkong yang belum memiliki Surat Izin Usaha Perdagangan (SIUP), merk dagang mereka sangat sederhana, yaitu cukup dengan nama dan alamat saja. Anggota kelompok usaha keripik singkong yang sudah mempunyai SIUP hanya satu orang, yaitu Pak Taufik. Belum mempunyai SIUP ini menjadi kendala tersendiri bagi sebagian besar kelompok usaha keripik singkong di Desa Sumber Anyar, hal ini dikarenakan keripik yang mereka jual belum mempunyai izin usaha resmi dari pemerintahan. Sementara untuk proses pengemasan, hampir semua anggota kelompok usaha keripik singkong di Desa Sumber Anyar menggunakan cara manual atau cara tradisional. Cara yang dilakukan adalah keripik singkong hanya dibungkus plastik ukuran kecil, kemudian dilipat dan dipanasi di atas lilin untuk merekatkan bungkusan agar kedap udara. Belum adanya mesin pres-presan menjadi kendala tersendiri saat proses pengemasan.

Pada tahapan yang terakhir yaitu tahap pemasaran, model pemasaran yang dilakukan oleh sebagian besar anggota kelompok usaha keripik singkong di Desa Sumber Anyar yaitu hanya dengan mengantarkan sendiri dan menitipkan keripik singkong mereka di warungwarung kecil. Jika stok keripik singkong di warung-warung tersebut masih banyak, maka mereka tidak akan memproduksi keripik singkong dulu sampai keripik singkong sebelumnya habis terjual. Hal ini mengakibatkan produksi keripik singkong oleh kelompok usaha ini tidak berjalan tiap hari. Untuk jangkauan pemasaran, sebagian besar anggota kelompok usaha keripik singkong ini hanya berani memasarkan didaerah Maesan saja, dan itupun dimasukkan ke warung-warung atau sekolahsekolah yang dekat dengan rumah mereka. Belum beraninya mereka memasarkan dalam skala besar masih menjadi kendala utama bagi kelompok usaha keripik singkong ini dalam hal jangkauan pemasaran.

Harga keripik singkong yang dititipkan ke warung-warung atau sekolah-sekolah tersebut mereka jual dengan harga yang cukup murah, yaitu Rp. 400 untuk kemasan 100 gram dan Rp. 900 untuk kemasan 250 gram. Kemudian pemilik warung tersebut akan menjual kembali dengan harga Rp. 500 per 100 gram dan Rp. 1.000 per 250 gram. Frekuensi penitipan keripik singkong di warung-warung atau sekolah tersebut adalah tiga hari sekali. Untuk sekali penitipan, jumlah keripik singkong yang mereka titipkan adalah sebanyak 1 renteng yaitu sekitar 11 bungkus. Rata-rata jumlah warung yang menjadi tempat penitipan keripik singkong mereka adalah sebanyak 5 warung dan tiap hari selalu bergantian memasukkan keripik singkong. Pesanan keripik singkong paling banyak dipesan jika sudah memasuki hari raya atau lebaran. 


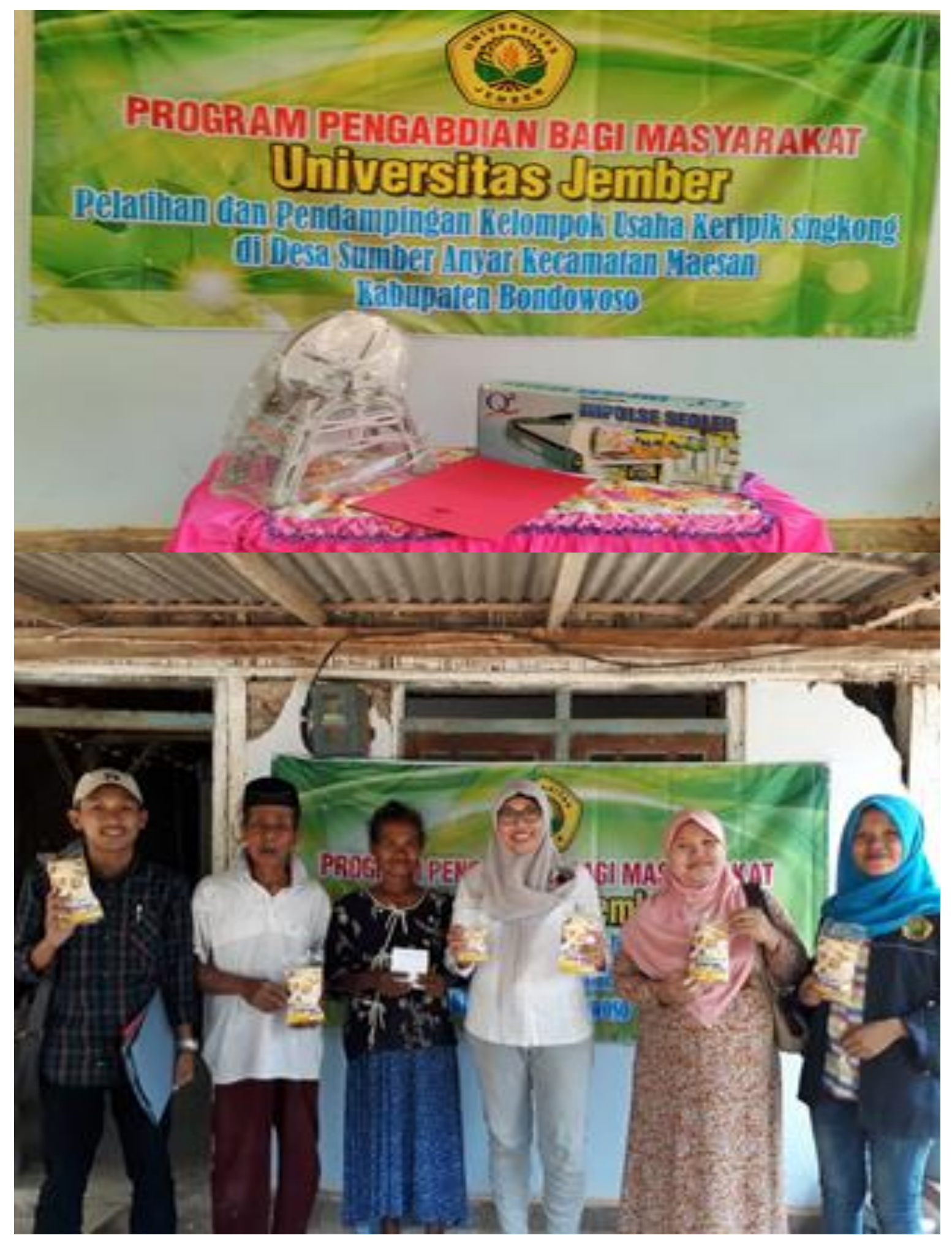

Gambar 1.Sasaran Pengabdian Masvarakat Kelompok Usaha Keripik Singkong

Sebagian dari anggota kelompok usaha keripik singkong tidak memiliki kebun singkong sendiri, sehingga mereka selalu harus beli bahan baku singkong tersebut. Kualitas singkong yang mereka beli masih belum sebagus kualitas singkong yang berasal dari Kabupaten Bondowoso. Singkong yang mereka jadikan sebagai bahan baku tergolong keras dan susah

untuk dikelola menjadi keripik. Hampir sebagian besar anggota kelompok usaha keripik singkong di desa ini belum pernah mendapatkan singkong yang sesuai harapan, dan sering menggunakan bahan perenyah. Hal ini menyebabkan untuk pemasaran keripik singkong ini menjadi terbatas dan kalah saing dengan keripik singkong yang berasal dari Bondowoso. 
Pelatihan dan Pendampingan Kelompok Usaha Keripik Singkong

Usaha keripik singkong "Pak Mul" adalah usaha keripik singkong yang kami pilih sebagai mitra pelatihan dan pedampingan pembuatan keripik singkong. Dimana tahap pelatihan dan pendampingan pembuatan keripik singkong diawali dengan menyiapkan semua bahan dan bumbu untuk membuat keripik singkong. Bahan utama yang akan dipakai adalah singkong. Memilih Singkong yang masih segar. Singkong segar memiliki ciri; tanah masih menempel pada kulitnya, pada bagian pangkal umbi masih terlihat putih dan tidak ada garis-garis biru kehitaman. Hindari membeli umbi singkong yang berkulit kusam, layu, pada pangkal sudah terlihat biru kehitam-hitaman.

Singkong dikupas kemudian di cuci bersih. Singkong dirajang Mesin Perajang Singkong otomastis untuk mendapatkan ukuran seragam dan tipis dan tidak lagi menggunakan pasrat. Tingkat ketebalan potongan singkong tidak boleh terlalu tebal ataupun terlalu tipis. Biasanya dalam proses pemotongan singkong manual dilakukan dengan menggunakan pasrat, dimana ketebalan potongan singkong tidak bisa disamaratakan dan membutuhkan waktu yang sangat lama dalam proses pemotongan singkong yang berimbas pada jumlah produksi keripik singkong layak jual juga kurang optimal atau dapat dikatakan dalam proses penyortiran kripik singkong yang layak jual masih ditemukan keripik singkong yang tidak layak jual dengan jumlah cukup besar, sehingga perlunya alat bantu berupa alat pemotong singkong untuk meminimalisir hal tersebut dan efisiensi waktu.

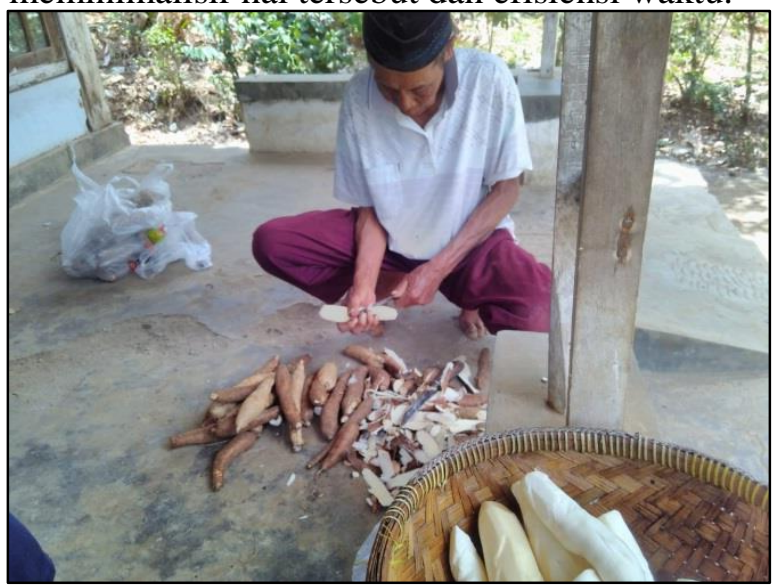

Gambar 2. Proses Pengupasan Singkong

Singkong selanjutnya digoreng dengan api kecil sampai setengah matang kemudian melanjutkan menggoreng singkong dengan panas yang maksimal sampai kering. Keripik yang sudah matang selanjutnya ditiriskan minyaknya dengan menggunakan mesin peniris sampai tidak ada minyak yang menempel pada keripik. Setelah ditiriskan maka keripik singkong dapat diberi bumbu sesuai dengan variant rasa yang akan dibuat. Keripik yang sudah diberi bumbu kemudian ditimbang sesuai dengan berat yang diinginkan menggunakan mesin timbang. Setelah ditimbang, Singkong kemudian dimasukkan dalam plastik kemasan yang telah diberi label atau merk pada kemasannya.

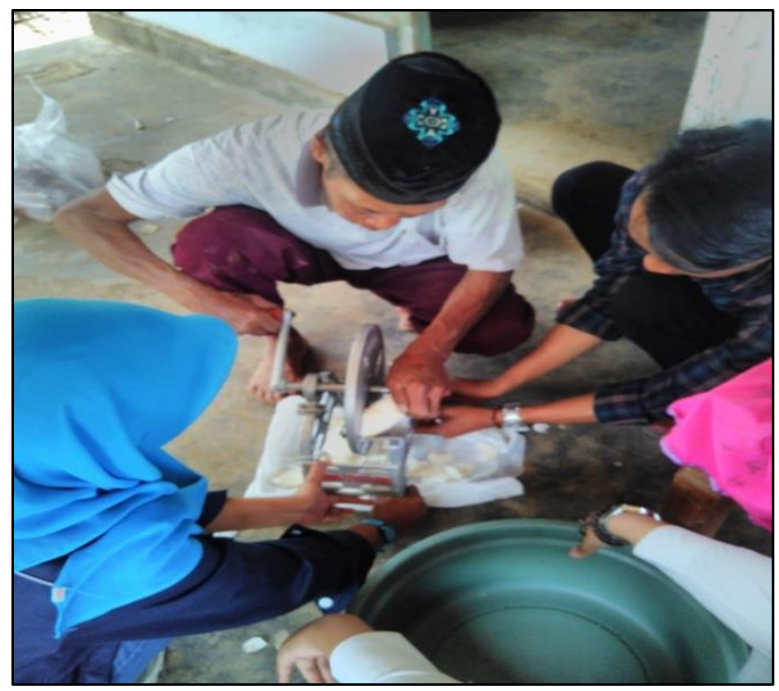

Gambar 3. Proses Pengupasan Singkong dengan Alat Bantu

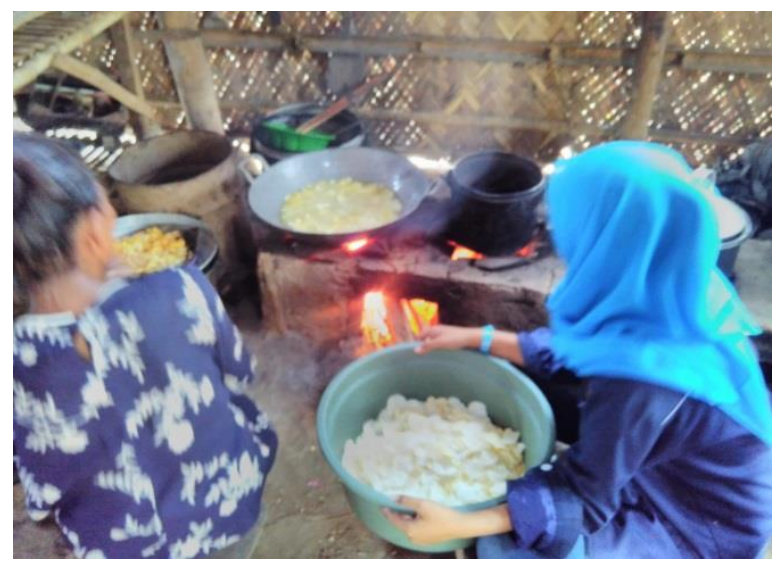

Gambar 4. Proses Penggorengan Keripik Singkong

Untuk membuat keripik singkong yang empuk, merebus irisan singkong dengan panci presto atau cukup merebus dengan air mendidih. Kemudian, biarkan hingga dingin. Irisan singkong digoreng dengan menggunakan api besar. Perbandingan terbaik untuk menggoreng antara minyak dan singkong adalah 3:1. Hasil pembuatan keripik bisa dibilang sempurna, jika pencampuran bumbu dan singkong tidak tampak basah. 


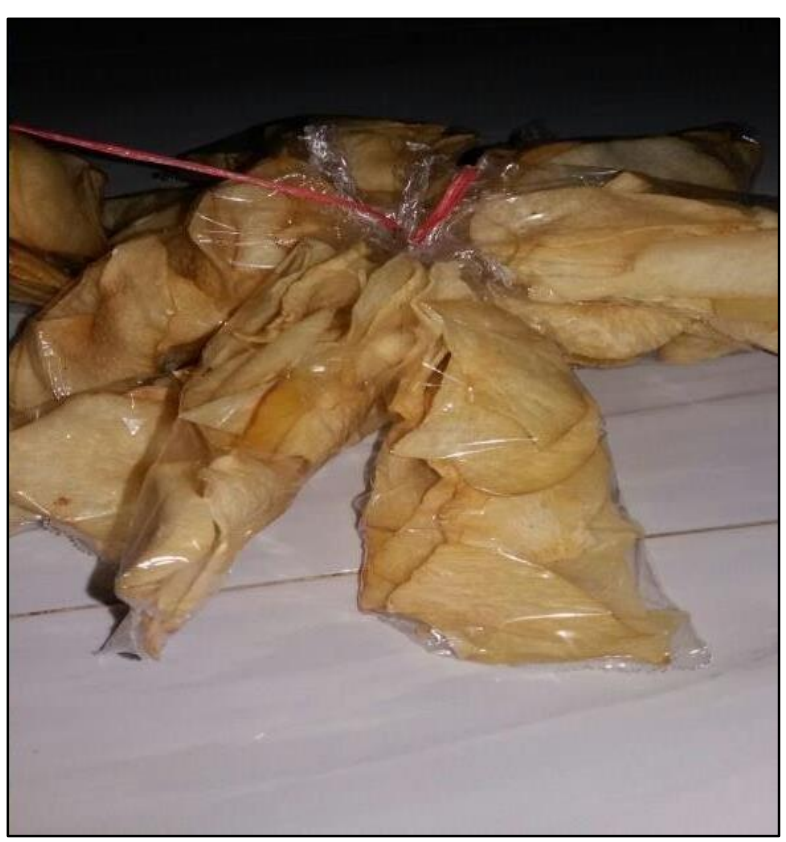

Gambar 5. Kemasan Keripik Singkong

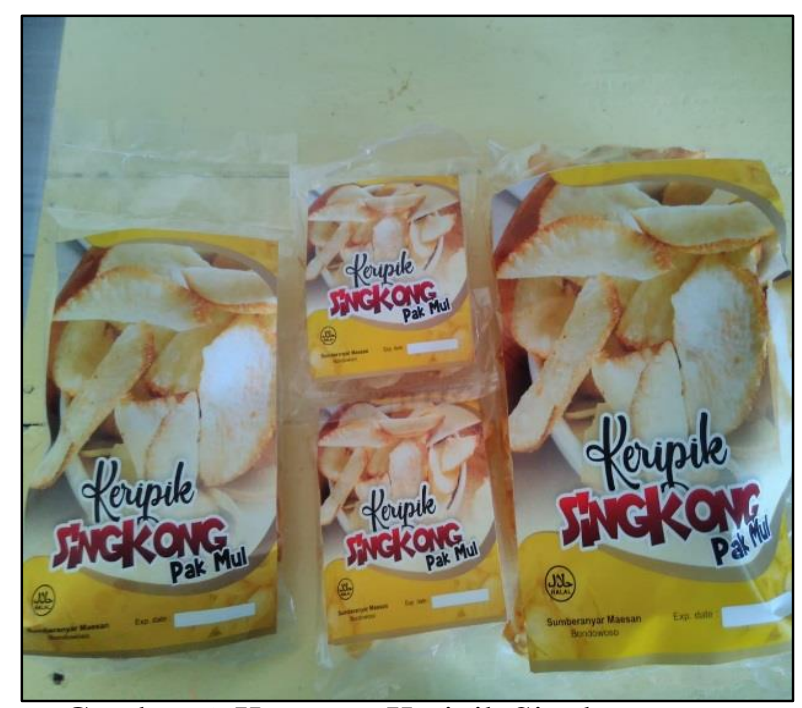

Gambar 6. Kemasan Keripik Singkong yang

Telah Diberi Label dan Merk

\section{KESIMPULAN}

Usaha keripik singkong "Pak Mul" sebagai mitra percontohan belum pernah melabeli kripiknya atau mengurus Surat Izin Usaha Perdagangan (SIUP) karena skala usahanya yang masih door to door atau dari warung ke warung. Sehingga saha keripik singkong "Pak Mul" perlu duberikan bantuan untuk memiliki label dan desain pembungkus keripik singkong yang lebih modern dan menarik untuk dijual. Sehingga Usaha keripik singkong "Pak Mul" bisa jauh lebih berkembang dari sebelumnya.

Kegiatan diversifikasi komoditas singkong memaksimalkan hasil pertanian yang merupakan salah satu komoditas yang unggul di lokasi kegiatan pengabdian masyarakat dan diharapkan dapat meningkatkan perekonomian masyarakat sekitar. Kegiatan tersebut mendapatkan respon yang cukup positif dari masyarakat dan pemangku kepentingan dan ke depan bisa diberikan tindak lanjut.

\section{DAFTAR PUSTAKA}

Amzeri, A. 2016. Profil Pengembangan Jagung Madura. Penerbit: UTM Press.

Casson, M. 2012. Entrepreneurship: Teori, Jejaring, Sejarah. Terjemahan. Penerbit: Rajawali Pers.

Efendy, M. 2012. Garam Rakyat: Potensi dan Permasalahan. Penerbit; UTM Press.

Rahayuningsih, E.S. 2016. Profil Ubi Кауu. Penerbit: UTM Press.

\section{Profil Tenaga} Kerja Madura. Penerbit: UTM Press.

Saputro, S.D. 2016. Profil Pendidikan Madura. Penerbit: UTM Press. 